\title{
Verbal processes in English and Spanish: a functional perspective to research articles on discourse analysis
}

\author{
Processos verbais em inglês e em espanhol: uma perspectiva funtional \\ para artigos de pesquisa sobre análise do discurso \\ Daniel Rodríguez-Vergara \\ Universidade Nacional Autônoma do México
}

\begin{abstract}
In this paper we present the results of an analysis of verbal processes and locution constructions in two corpora, one with papers from Anglophone journals, and one from Hispanophone ones. Our main interest was to build up a semantic-grammatical profile of how verbal and locution structures are constructed in the discipline of Discourse Analysis, and see if there were similarities and/or differences in the two corpora. The results showed that there are significant differences in terms of verbal process ratio, metaphoric locutions, most frequent verbal processes, and projection.
\end{abstract}

Keywords: verbal processes; research articles; discourse analysis.

Resumo: Neste artigo, apresentamos os resultados de uma análise dos processos verbais e das construções de locuções em dois corpora, um com artigos de revistas anglófonas e um de revistas hispanófonas. Nosso interesse principal foi traçar um perfil semânticogramatical de como estruturas verbais e de locução são construídas na área da Análise do Discurso, e verificar se havia similaridades e/ou diferenças nos dois corpora. Os resultados mostraram que há diferenças significativas em termos da relação processos verbais, locuções metafóricas, processos verbais mais frequentes e projeção.

Palavras-chave: processos verbais; artigos de pesquisa; análise do discurso. 


\section{Introduction}

The work presented in this paper forms part of a research project developed at the National Autonomous University of Mexico (UNAM), which, in turn, is part of a major project, Systemics Across Languages (SAL) in its Latin American version. The Mexican project, Verbal Processes in Academic Writing in the Light of Systemic Functional Grammar, has the purpose of exploring Spanish verbal clauses and locution constructions in the academic register of humanistic Daniel areas. In turn, the main goal of the SAL project is to study the relaRodrígueztionship between grammar and discourse from a typological point of view. Both projects analyze language from the perspective of Systemic Functional Linguistics (HALLIDAY, 1985, 1994; HALLIDAY; MATTHIESSEN, 2004, 2014).

The humanistic area chosen for the study presented here is Applied Linguistics, and most specifically, Discourse Analysis (DA), which is one of the most worked disciplines at UNAM's Applied Linguistics Department, the others being Sociolinguistics and Psycholinguistics. Although all those disciplines belong to the Applied Linguistics area (or to the most general one of Linguistics), each of them use different methods, and as a result, the papers where research results are published take different forms depending on the particular discipline from which they are produced (HYLAND, 2006). Thus, we were interested in building up a semantico-grammatical profile of how verbal and locution structures are constructed in papers on DA written in English and Spanish, in order to see if there were similarities and/or differences in those two languages.

In this paper we present the results of an analysis of verbal processes and locution constructions in papers from both Anglophone and Hispanophone journals. The structure of the article is as follows. First, we present the part of the systemic functional theory that is relevant for the study of verbal processes. Secondly, we present the methodology, where we report how the data was collected and analyzed. Thirdly, we present the results and their discussion in terms of frequency of verbal processes, metaphoric locutions, most frequent verbal processes, and projection in verbal clauses. Finally, we conclude with a summary and recommendations. 


\section{Theoretical background}

Systemic Functional Linguistics is a social semiotic theory that emphasizes the communicative function of language and whose main interest is to explain the relationship between text and context. It is functional as opposed to formal (MATTHIESSEN; TERUYA; LAM, 2010) in the sense that language is described principally by means of how it is used in societies and for which purposes, and not by means of what is the speakers' language knowledge like. On the other hand, it is systemic as opposed to structural in that it gives priority to the notion of 'paradigm' over that of 'syntagm'; i.e., it is concerned mostly with the linguistic choices that are available to speakers in the act of communication.

In trying to explain the relationship between text and context, SFL postulates three contextual variables: field, tenor, and mode of dis-

Verbal

processes in

English and Spanish course. According to Halliday and Matthiessen, field refers to "the nature of the social and semiotic activity and to the domain of experience this activity relates to." Tenor refers to "the roles played by those taking part in the socio-semiotic activity and to the values that the interactants imbue the domain with." And mode refers to the role "being played by language and other semiotic systems in the situation" (2014, p. 33).

In the text-context hook-up hypothesis (HASAN, 1995), the contextual variables correlate with three metafunctions: ideational, interpersonal, and textual. The ideational metafunction splits into two components, experiential and logical, and resonates with field of discourse. At the level of lexicogrammar, the experiential component includes the system of TRANSITIVITY, and generates configurative structures; in turn, the logical component includes the system of CLAUSE COMPLEXING, and generates iterative structures.

Secondly, the interpersonal metafunction resonates with tenor of discourse; it includes the systems of MOOD, MODALITY, and APPRAI$\mathrm{SAL}$, and generates prosodic structures in the lexicogrammar. Finally, the textual metafunction resonates with mode of discourse; it includes the systems of THEME and FOCUS, and generates periodic structures.

For the present study, we will focus on the ideational metafunction, which includes the systems of TRANSITIVITY and CLAUSE COMPLEXING. On the one hand, TRANSITIVITY is the system that construes reality in terms of configurative (multivariate) structures where the most important element is a Process that is realized by a verbal group in the clause. In configurative structures, a Process might include up to three Participants revolving around it, and a number of Circumstances (see Table 1). 
Table 1 - Configurative (multivariate) structure with a Process, three Participants, and a Circumstance

\begin{tabular}{|c|c|c|c|c|}
\hline \multicolumn{2}{|c|}{ a-----------x-------------b----------c-----------d } \\
\hline Somebody & gave & someone & something & somewhere \\
\hline Participant & Process & Participant & Participant & Circumstance \\
\hline
\end{tabular}

Transitivity structures are configurative (or multivariate) because Daniel Processes, Participants, and Circumstances stand in different kinds of reRodríguezlation to one another (MATTHIESSEN; TERUYA; LAM, 2010). For example, in the clause structure in Table 1, Somebody, gave, someone, something, and somewhere all have different values ( $\mathrm{a}, \mathrm{x}, \mathrm{b}, \mathrm{c}$, and $\mathrm{d}$, respectively).

According to Halliday and Matthiessen (2014), there are six Process types: verbal, mental, behavioral, material, existential and relational (see Figure 1). Three of them are basic: the ones related to the world of abstract relations (relational), to the world of consciousness (mental), and to the physical world (material).

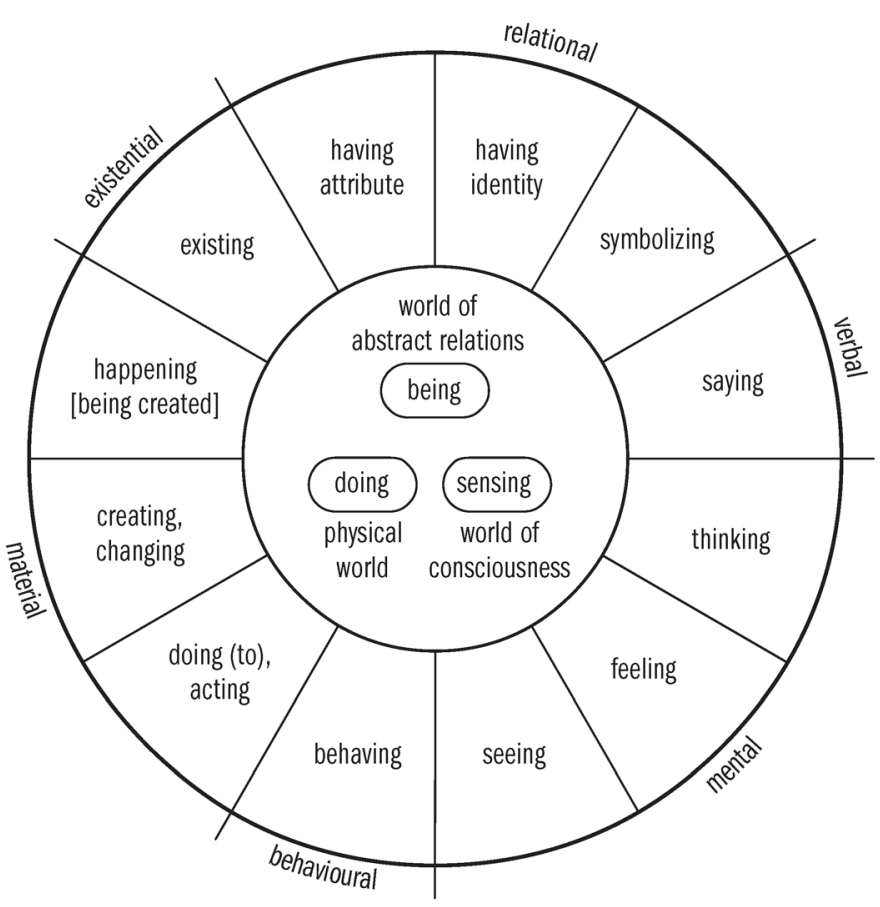

Figure 1. Types of Process

Source: Halliday; Matthiessen (2014, p. 216) 
In particular, verbal processes represent symbolizations involving a source (the Sayer) that can be conscious or unconscious. When conscious, the process is typically a human activity such as speak, talk, blame, etc.; when unconscious, the process typically involves a semiotic activity such as indicate, present, suggest, etc. In a verbal clause there is often a Sayer, a Receiver, a Verbiage, and sometimes a Target (see Tables 2 and 3).

Verbal

Table 2 - Verbal clause with three Participants and a Circumstance processes in English and

\begin{tabular}{|c|c|c|c|c|}
\hline he & had said & something & (to him) & with obvious good intentions. (Text 3) \\
\hline Sayer & Process & Verbiage & Receiver & Circumstance \\
\hline
\end{tabular}
Spanish

Table 3 - Verbal clause with Target

\begin{tabular}{|c|c|c|}
\hline $\begin{array}{c}\text { Adult educators } \\
\text { such as Welton (1997) }\end{array}$ & critique & $\begin{array}{c}\text { this co-optation } \\
\text { of civil society. (Text 10) }\end{array}$ \\
\hline Sayer & Process & Target \\
\hline
\end{tabular}

As can be seen in Table 3, Targets appear only when the process denotes a positive or negative judgment towards someone or something (cf. MARTIN; WHITE, 2005).

Verbal, as well as mental processes, not only generate configurative structures but also iterative ones. As already mentioned, the general system within the ideational metafunction that generates such types of structure is CLAUSE COMPLEXING. Verbal and mental clauses function within this system when they "set up one clause as the representation of the linguistic content of another either as ideas in a mental clause of sensing or locutions in a verbal clause of saying" (MATTHIESSEN; TERUYA; LAM, 2010). Ideas and locutions are two types of logico-semantic relations that can be manifested para- or hypotactically (see Tables 4 and 5).

Table 4. Paratactic verbal projection

\begin{tabular}{|c|c|c|}
\hline She & responded, & "Okay, but don't call me honey." (Text 3) \\
\hline Sayer & Process & Locution: parataxis \\
\hline \multicolumn{2}{|c|}{ Projecting clause } & Projected clause \\
\hline
\end{tabular}


Table 5. Hypotactic verbal projection

\begin{tabular}{|l|l|l|}
\hline They & argue & $\begin{array}{l}\text { that the traditions of poststructuralism have more to offer } \\
\text { than has been explored. (Text 1) }\end{array}$ \\
\hline Sayer & Process & Locution: hipotaxis \\
\hline \multicolumn{2}{|l|}{ Projecting clause } & Projected clause \\
\hline
\end{tabular}

In a paratactic relationship (Table 4), both the projecting and the

Daniel

Rodríguez-

Vergara

148

Table 6. Iterative (univariate) structure with projected clauses

\begin{tabular}{|c|c|c|}
\hline a------------------------------a ${ }^{\text {ii }}$ \\
\hline Somebody said & that someone thought & that someone had said \\
\hline Clause 1 & Clause 2 & Clause 3 \\
\hline
\end{tabular}

Different to multivariate structures, where the elements in a structure have different values $(a, x, b$, etc.), in a univariate structure, elements have the same value $\left(a, a^{i}, a^{i}\right)$. For example, in the clause complex in Table 6, all three clauses are ranking (i.e. non-embedded).

Locutions in a tactic relationship are considered 'congruent' grammaticalizations of ideational meaning. Among other things, in a congruent grammaticalization, events are expressed through clauses, and things are expressed through nouns. However, ideational meaning can also be grammaticalized incongruently by means of 'grammatical metaphor' (HALLIDAY; MATTHIESSEN, 2014), where events are expressed through nouns. Grammatical metaphors of locution involve the nominalization of the projecting clause, whereas the projected clause becomes a post-modifier of the nominalized clause. For example, when the clause complex in Table 5 is packed as a grammatical metaphor, the resulting construction is their argument that the traditions of poststructuralism have more to offer than has been explored, where the projecting clause they argue has become a noun group (their argument), and the projected clause has become a post-modifier of such noun group. 
In the study presented in this paper, we explored in our corpora the ratio of verbal clauses, metaphorical locutions, the most frequent verbal processes, and their projecting characteristics. For the analysis, we followed the methodology presented below.

\section{Methodology}

\section{Data collection}

For the present study, we collected two corpora, one of ten research Verbal articles in English and one of ten in Spanish (see Apendix). Since processes in we were interested in how verbal and locution structures are constructed in the discipline of DA, we looked for articles that contained the term 'discourse analysis' in English, or in the case of Spanish, 'análisis del discurso'. For the articles in English, we used the English and Spanish Internet database ERIC (Education Resources Information Center), whereas for the articles in Spanish, we used REDALYC (Network of Scientific Journals from Latin America, the Caribbean, Spain and Portugal). In both cases, we used the 'advanced search' in order to specify that the returned articles contained the term 'DA'. However, we were surprised to find articles with that term only in English but not in Spanish; so, in the case of the latter, we had to select articles that contained the word 'discurso' only. The selection of the articles from the returned results in each search engine was random in that we chose the first ten articles of the ERIC database, and the first ten articles of the REDALYC database published in Mexican linguistic journals.

\section{Data analysis}

After the articles were gathered, we determined the number of finite clauses in every article in order to use it to quantify verbal processes in relative, not absolute terms. In that way, we avoided the problem of longer texts having a higher probability of containing more processes than shorter ones. Later, we highlighted and counted all verbal clauses in each article and obtained a total percentage of verbal processes for every article and for every corpus.

After that, we determined the number of metaphoric locutions in each article and each corpus. We obtained the percentages by dividing in every article the number of metaphoric locutions with the number of finite clauses. As a criterion for the selection of meta- 
phoric locutions, we quantified only the nominalizations that can be 'unpacked' into a complete clausal version (CHRISTIE; DEREWIANKA, 2008). Generally speaking, complex noun groups can be unpacked into complete clauses (allusion to other regional examples $\rightarrow$ other regional examples were alluded), but simple noun groups cannot (such critiques $\rightarrow$ ???).

We also determined the ten most frequent verbal processes in every corpus, and, for every process, the number of times that

Daniel they projected a paratactic or hypotactic locution. Finally, the re-

Rodríguez-

Vergara

150 sults in every corpus were compared, as presented in the following section.

\section{Results and Discussion \\ Frequency of verbal processes}

We will start by presenting the percentages of verbal processes in both corpora (see Figure 2). We obtained the percentages in each article by dividing the number of verbal processes with the number finite clauses. In total, the English corpus has a higher ratio of verbal processes than the Spanish one (27.75\% vs. $22.95 \%)$. Also, the English corpus presents the article with the highest percentage (Text 3), whereas the Spanish corpus presents the five articles with the lowest percentages (Texts 1 , 2, 3, 6 and 8).

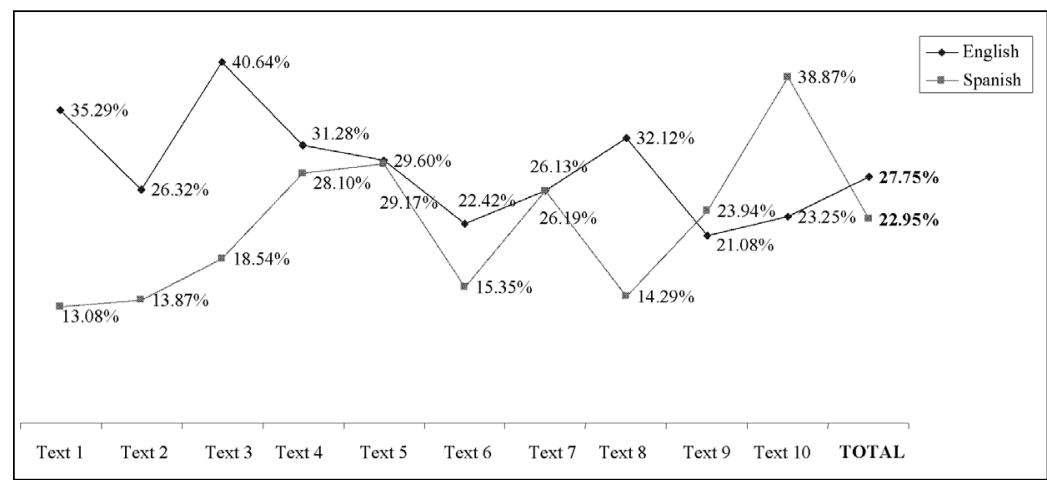

Figure 2. Verbal process percentages

In order to speculate on the possible causes for which the English articles have a higher percentage of verbal processes, we examined the verbal clauses in the English article with the highest percentage (Text 3) and their co-texts of occurence. In general, we observed that the En- 
glish article, although it does not present empirical research, has a clear statement of purpose, where the author actually uses a number of verbal processes:

(1) In order to show the influence and continuing relevance of Presentation of Self, I'll briefly define and illustrate the concepts that are key for discourse analysts: framing and face, and explain their relation to the theoretical underpinnings outlined in Presentation. I will then suggest the roles they play in discourse analysis, [...]. After that, I'll relate a personal encounter I had with Goffman and explain the insight and inspiration this encounter afforded me. Finally, I'll briefly note another source of inspiration... (Text 3)

In this fragment, which is the second and last paragraph of Verbal processes in English and Spanish

the introduction, the author uses verbal processes (shown in bold) to outline the purposes and contents of the article, employing always the first person singular. Such processes are clustered into one paragraph because they function together to construe a move in the introduction: the part where the author announces his/her research (SWALES, 1990, 2004).

In the same article, we observed more clustering of verbal processes in other paragraphs. For instance, in the body of the paper there is a paragraph where the author reviews the work of a linguist by reporting her:

(2) In a recent paper (Schiffrin 2006) she emphasizes Goffman's distinction between signs given and signs given off in order to explain his notion of self as a social construction. She then outlines the influence of this distinction as well as his view of face and the related concept of ritual. Drawing on this theoretical framework, she demonstrates how reference-that is, choice of nouns and pronouns-intended to tell about individuals the speaker is talking about, also unintentionally express who the speaker is. (Text 3)

In this paragraph, the verbal processes in bold are used to report Schiffrin's work in a fashion similar to the one we observed in (1). Actually, the processes in (1) and (2) are very similar; the difference is that the ones in (1) are in the first person, whereas the ones in (2) are in the third person. 
One more paragraph where the author uses several verbal processes that work together to fulfill a specific goal is (3). In this fragment of the paper, the author tells a story that has to do with linguist Erving Goffman:

(3) While in Philadelphia for the on-campus interview, I was honored to be invited to lunch at the home of Erving Goffman and his wife, the linguist Gillian Sankoff. During conversation over lunch, I told of an

Daniel Rodríguez-

Vergara experience I had had at yet another interview, a story I had already told a number of times, always with the same point-a point that, until then, my listeners had always agreed was self-evident. But when I told the story on this occasion, Goffman showed me a perspective that I had missed-a perspective that illustrates the theoretical framework I described above. (Text 3 )

Differently to (1) and (2), this paragraph contains some verbal processes in the first person, and others in the third. Since the function that the clustering of the processes here fulfills is changing the register into that of telling a story, it is natural that all the processes are not exclusively in the third or first person. Moreover, as can be read in the paragraph, the author not only tells a story, but tells the story of how he had told another story to Erving Goffman. As a consequence, the paragraphs in the paper following (3) also contain verbal process clustering similar to this one.

In sum, the motivation for the high frequency of verbal processes in research articles might be related to the functions that some stages of the articles fulfill. As we observed, such functions can include outlining purposes and contents of an article, reporting work from other researchers, and even telling stories. Those functions might elicit the use of verbal processes to the point of forming clusters of them.

\section{Metaphoric locutions}

In this section we present the percentages of metaphoric locutions in each article and in each corpus (see Figure 3). In total, the English corpus has a slightly higher percentage than the Spanish one (6.71\% vs. 5.10\%). In addition, the English corpus has the four articles with the highest percentages (Texts 1, 2, 4 and 5), whereas the Spanish corpus has the article with the lowest percentage (Text 2). 


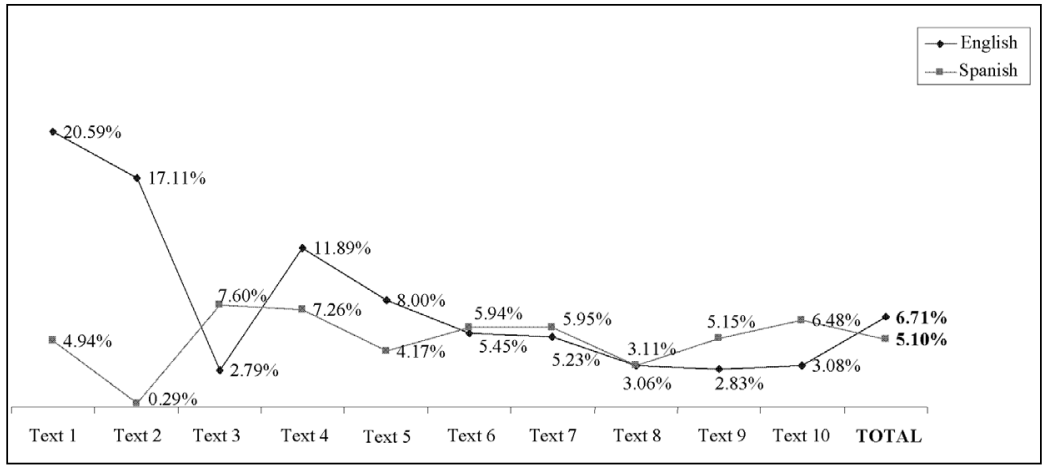

Figure 3. Metaphoric locution percentages

Again, in order to speculate on the possible causes for which the English articles have a higher percentage, we examined the metaphoric locutions in the English article with the highest percentage (Text 1). In absolute terms, this article contains 21 metaphorical locutions. Generally speaking, the article is a response to another paper on the role of discourse analysis in the field of education. We present below a paragraph from the article that contains six metaphoric locutions.

(4) It is impossible not to conclude without at least some response to the totalising tendency of postmodern discourse itself, and its sweeping, ahistorical assertions. Here Marxism again serves as an example, although, again, other cases could be cited. Ritual assertions of the supposed totalising tendencies of Marxist thought never allude to important distinctions within this vast, longstanding and often contested interpretive tradition. Hence, no importance is accorded to the epistemological break in Marx, and of basic distinctions between the earlier scientific Marxism, and the later Critical form, which was rigorously critical of the claims of the natural sciences, and their pretensions to a universal methodology. The same blindness to the history of thought presumably lies behind the conventional postmodern refusal to acknowledge important nineteenth century precedents to the current critique of universalism, and the scientistic pretensions to a monolithic methodology. Both these points formed an important inspiration for both Wilhelm Dilthey's (1926) hermeneutics, and the phenomenology of Edmund Husserl (1965), to cite just two examples. (Text 1$)$
Verbal

processes in English and Spanish 
In this paragraph, the metaphoric locutions are shown in bold, and within those locutions, the nominalized processes are underlined. The nominalized processes are response, assertions $(\times 2)$, claims, refusal, and critique. If we take any of those nominalizations and unpack it back to the verbal form, we can reconstruct the locution in a clausal form. For instance, the conventional postmodern refusal to acknowledge important nineteenth century precedents can be regrammaticalized as the conventional postmodernists refused to acknowledge important nineteenth century

Daniel Rodríguez-

Vergara precedents.

One point made by Halliday e Matthiessen (1999) is that grammatical metaphor plays an important role in the unfolding of text. They state that, as well as in the time of an individual (ontogenesis) (cf. DEREWIANKA, 1995), grammatical metaphors appear later than their respective congruent forms in the time of the process of the unfolding of text (logogenesis). We speculate that the article in English uses more metaphorical locutions because the author is constantly making reference to verbal events that were already mentioned in the text or in some other text, thus using the metaphoric constructions as anaphors. For instance, the metaphoric locution the claims of the natural sciences refers to something that people within the natural sciences said sometime somewhere.

\section{Most frequent verbal processes}

In this section we present the five most frequent verbal processes in each corpus (see Figure 4). In the case of English, three of the five processes are socio-semiotic activities: argue, present and describe. Socio-semiotic activities refer to the field of discourse in that they describe what is going on in the context where participants are using language (HALLIDAY; MATTHIESSEN, 2014). In that sense, such processes involve a complex act of saying since in order to argue, present or describe something to someone, the speaker has to use rhetorical and cognitive strategies, especially when arguing. In contrast, the fourth most frequent process, say, can be reduced to a simple act of uttering. As for the fifth most frequent process, suggest, it is mainly used in research articles to state research results in tentative rather than absolute terms. Such 'tentativeness' in academic writing has been referred to as 'hedging' (HYLAND, 1998). 


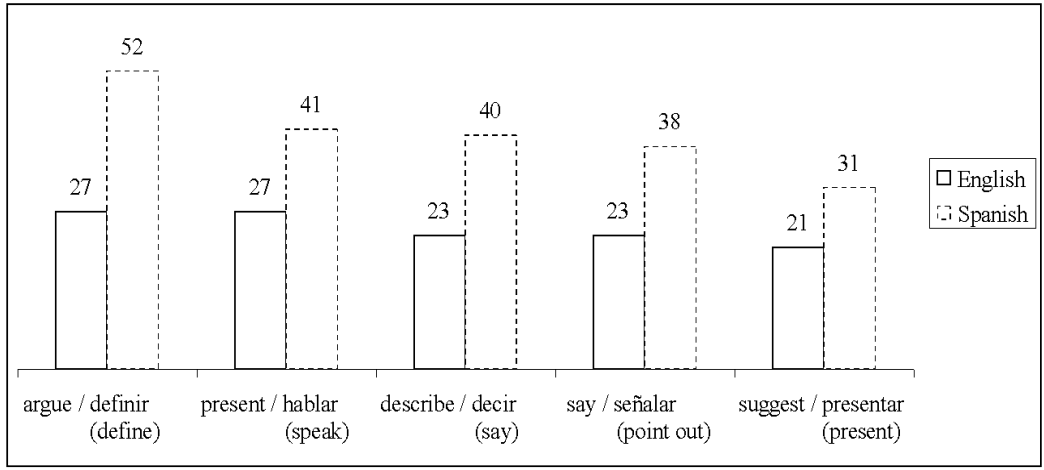

Figure 4. Most frequent verbal processes

In Spanish, two of the five processes are socio-semiotic activities (definir and presentar), two refer to acts of uttering (hablar and decir), and señalar (point out) is a process that is mostly used in the research articles for purposes of citation (the others can also be used for such purposes but not as frequently). The fact that definir (define) is the most frequent process might pinpoint a general trend under which authors are concerned with defining abstract concepts utilized in the DA discipline.

In the same vein, the high frequency of socio-semiotic activities being used in verbal clauses might also be due to the fact that the articles of the corpus have to do with DA. Brown and Yule (1983, p. ix) define discourse analysis as the study of "how humans use language to communicate." That means that the objects of study that are dealt with in the articles are a reflection of human linguistic activity. In that sense, in order for writers to construe the world of human communication, they use socio-semiotic processes in their clauses.

\section{Projection in verbal clauses}

We will now present the number of clauses that project locutions for each of the five most frequent processes (see Figure 5). In the case of English, three of the five processes are used to project locutions: argue, say and suggest. The first one has more projections than non-projections (15 vs. 12). Of the 15 projections, 12 are hypotactic and three are a combination of hypotaxis with parataxis. We show the latter ones below.

(5) The editors of Volume 5 argue in their introduction to James Avis's chapter that further education teachers 'are being forced to adopt unwelcome professional identities'... (Text 9)
Verbal

processes in English and Spanish 
(6) Fairclough argues that the analysis of discourse is key to understanding these transformations because 'one cannot make sense of them without thinking about language'... (Text 9)

(7) Luke $(1995,3)$ argues there is a need to develop 'new knowledge that demonstrates how particular perspectives, methods, and "truths" are made available, selected, and framed for the work of education'... (Text 9)

As can be seen, the author of examples (5-7) starts constructing Daniel the projections as though they were hypotactic, using the compleRodríguezmentizer that in two of the examples. Nevertheless, the paratactically projected material, which is between quotation marks, eventually incorporates into the syntax of the sentence. Examples (5-7) all appear in the same text, which suggests that the combination of parataxis and hypotaxis might be part of that author's style. However, Halliday and Matthiessen (2014) state that the combination of the two taxis types is one mode of projection in its own right, which they refer to as 'free indirect speech' (cf. THIBAULT, 1991, for an account of this phenomenon).

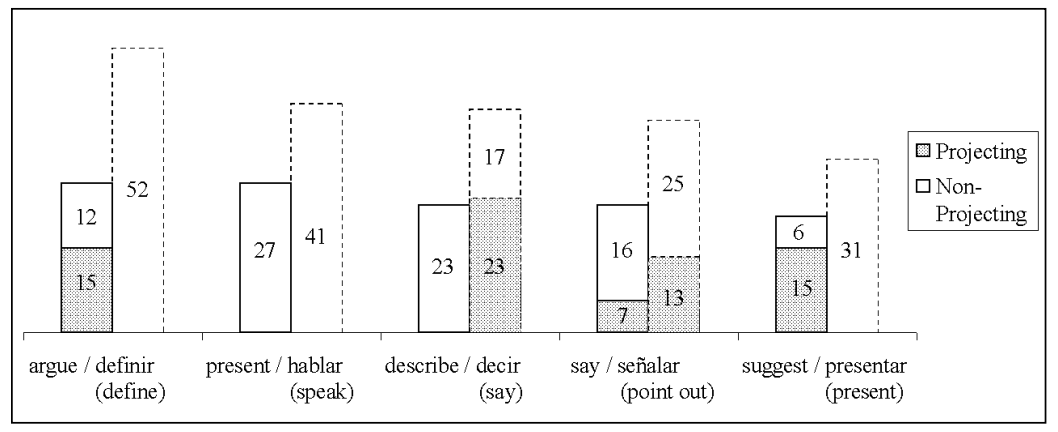

Figure 5. Projection in most frequent verbal processes

As opposed to argue, the process say has more non-projections than projections (16 vs. 7). Of the seven projections, four are hypotactic and three paratactic. We show the paratactic ones below.

(8) ...he said, "Thanks, honey. I'll do the same for you sometime." (Text 3)

(9) She said, "That's just the point. You're not my husband." (Text 3)

(10) One mother interviewed by the $B B C$, said of her own child: 'He was a normal happy boy until 13 months old, when he had the MMR injection. After that he went down hill very rapidly'... (Text 4) 
Paratactic projections (8) and (9) are from the article that we had mentioned already where the author tells the story of how he had told another story (Text 3). As for the process suggest, it has more projections than non-projections ( 15 vs. 6). All the projections with this process are hypotactic.

In Spanish, only two verbal processes are used to project locutions: decir and señalar. The former has more projections than non-projections (23 vs. 17). Of the 23 projections, 18 are hypotactic, three are paratactic, and two are a combination of both taxis types. We show the mixed ones below.

(11) Graham Green definió La Habana diciendo que era el lugar "where every vice was permissible"... (Text 5)

[Graham Green defined The Habana by saying that it was the place "where every vice was permissible"]

(12) Hemingway llegó a decir que le gustaba Cuba "because it had both, fishing and fucking"... (Text 5)

[Hemingway once said that he liked Cuba "because it had both, fishing and fucking"]

As well as the examples in English (5-7), here the paratactically projected material incorporates into the sentence that started as a hypotactic locution. However, we note that the author of examples (11) and (12) uses the original language in the quotation part of the projections. As we will see below, this author also uses the process señalar to quote fragments in the original language.

(13) Y señala que: "As an apparatus of symbolic power it (the nation as analytic strategy) produces a continual slippage of categories like sexuality". (Text 5)

[And he points out that: "As an apparatus of symbolic power it (the nation as analytic strategy) produces a continual slippage of categories like sexuality".]

(14) Louis Pérez señala en On Becoming Cuban que Cuba entró en el imaginario estadounidense como "the place of pleasures unavailable at home". (Text 5)

[Louis Pérez points out in On Becoming Cuban that he entered the American imagery as "the place of pleasures unavailable at home"] 
In total, señalar has 13 projections and 25 non-projections. Of the 13 , nine are hypotactic and four mixed. In addition to the constructions already presented, there were some others that we found to be frequent in both the English and the Spanish corpora but that we did not count as projections; they consisted on citations, either quoted or reported, introduced by a hypotactic clause with the conjunction as in English, or como in Spanish. Those clauses are similar in function to the Circumstances of angle described by Matthiessen (1995) of the type according

Daniel to, which, from the vantage point of APPRAISAL (Martin; White, 2005), are Rodríguezanalyzed as attributive expansions in the subsystem of ENGAGEMENT. We present two examples below.

(15) ...as Cheryl Hunt argues, 'it may be time to re-examine the nature of resistance itself'... (Text 9)

(16) El restablecer la dimensión de la sociedad "sin historia", como señala Claude Lefort (1986, 201), es una característica clave de la ideología de las sociedades modernas. (Text 4)

[Reestablishing the dimension of the society 'without history', as pointed out by Claude Lefort $(1986,201)$, is a key characteristic of modern society ideology.]

We know that the introductory clause (or interrupting clause, in the case of the Spanish sentence) is hypotactic because it is bound in the sense that it cannot stand for itself and because it is the one that contains the conjunction. However, analyzing the quotation as the main clause would be against the usual systemic analysis where the projected clause is dependent on the projected one. For that reason, we did not count such constructions as projections, and more research needs to be done in order to clarify their status.

\section{Conclusion}

In this article we have presented the results of an analysis of verbal processes and locution constructions in Anglophone and Hispanophone papers about DA. We observed that verbal process frequency was significantly higher in the English corpus. Also, the percentage of metaphoric locutions was higher in the English corpus, but the difference was minimal. After exploring the English text with the highest percentage of verbal processes, we realized that there are some paragraphs 
with the majority of their processes being verbal. We suggested that those paragraphs fulfill a specific function within the whole research article, e.g. outlining purposes of an article, reporting work from other sources, and changing the register. Also, after examining the English text with the highest percentage of metaphoric locutions, we inferred that a motivation behind the frequent use of such constructions was making reference to verbal events already mentioned earlier in a text or in some other text.

Verbal

We also noted that verbal processes that refer to socio-semiotic activities appear within the five most frequent processes in both corpora perhaps because they facilitate the construal of meaning in the DA discipline, where human communication has to be accounted for. of those most frequent processes, definir stands out as the most frequent processes in English and Spanish one in Spanish, showing authors' preoccupation to clarify abstract concepts. As for projecting constructions, we observed that some processes favor parataxis, some favor hypotaxis, and some appeared as a combination of the two types of taxis. In addition, there were some constructions that consisted of a hypotactic clause with the English conjunction as or the Spanish one como followed by a quote or a report. Although they look like projections, their status is not yet clear in the literature.

The results obtained here help us to understand the role that verbal and locution structures have in construing experience within the domain of DA. However, this is just one of a number of disciplines under the holistic area of Applied Linguistics. More research needs to be carried out in other disciplines (e.g. Sociolinguistics, Psycholinguistics) in order to see if there are correspondences and differences. Ultimately, scholars who are working in those disciplines and who are leaning how to read and write specialized academic material could benefit from accounts of how grammatical and semantic resources are deployed in such material.

\section{Appendix: Corpus references}

\section{English texts:}

1) WELCH, A. The discourse of discourse analysis: a response to Ninnes and Burnett. Comparative Education, v. 39, p. 303-306, 2003.

2) WANG, A.Y.; NEWLIN, M.H.; TUCKER, T.L. A discourse analysis of online classroom chats: predictors of cyber-student performance. Teaching of Psychology, v. 28, p. 222-226, 2001. 
3) TANNEN, D. Framing and face: the relevance of "The Presentation of Self" to linguistic discourse analysis. Social Psychology Quarterly, v. 72, p. 300-305, 2009.

4) O'DELL, L.; BROWNLOW, C.; Media reports of links between MMR and autism: a discourse analysis. British Journal of Learning Disabilities, v. 33, p. 194-199, 2005.

5) ALMEIDA, E. A discourse analysis of student perceptions of their communication competence. Communication Education, v. 53,

Daniel Rodríguez-

Vergara p. 357-364, 2004.

6) WODAK, R. Critical discourse analysis at the end of the 20th Century. Research on Language and Social Interaction, v. 32, p. 185-193, 1999.

7) SAARINEN, T. Position of text and discourse analysis in higher education policy research. Studies in Higher Education, v. 33, p. 719-728, 2008.

8) COTS, J. Teaching "with an attitude": critical discourse analysis in EFL teaching. ELT Journal, v. 60, p. 336-345, 2006.

9) WILSON, A.L. Learning to read: discourse analysis and the study and practice of adult education. Studies in Continuing Education, v. 31, p. 1-12, 2009.

10) IRVING, C.J.; ENGLISH, L.M. Partnering for research: a critical discourse analysis. Studies in Continuing Education, v. 30, p. 107-118, 2008.

\section{Spanish texts:}

1) ALDAMA, J.A. La construcción mítica del discurso nacionalista vasco. Tópicos del Seminario, n. 20, p. 113-128, 2008.

2) TORRES, G. Análisis semiótico del discurso visual de un trabajo plástico. Escritos: Revista del Centro de Ciencias del Lenguaje, n. 23, p. 91-108, 2001.

3) LEMUS, D. Entre el cielo y el infierno: la construcción de la identidad y el mundo indígena en el discurso religioso del siglo XVII: el caso de la relación de las misiones de la Companía de Jesús en la provincia de los maynas. Revista de Humanidades: Tecnológico de Monterrey, n. 24, p. 33-50, 2008.

4) GUITIÉRREZ, S. El discurso argumentativo: una propuesta de análisis. Escritos: Revista del Centro de Ciencias del Lenguaje, n. 27, p. 45-66, 2003. 
5) ÁLVAREZ, I. El discurso sexual como valor de identidad nacional de lo cubano. Revista de Humanidades: Tecnológico de Monterrey, n. 14, p. 13-35, 2003.

6) ESPINOSA, M. Discurso y tecnología: análisis conversacional de un foro de opinión. Razón y Palabra, n. 74, 2010.

7) BONAVITTA, P. Golpe de estado en Honduras: el discurso de Cristina Fernández. Razón y Palabra, n. 74, 2010.

8) HERAM, Y. Multimedios y discurso televisivo: el análisis de la revita 'Noticias'. Razón y Palabra, n. 73, 2010.

Verbal processes in

9) LOZANO, C.; PIÑUEL, J.L.; GAITÁN, J.A. Las verdades implantadas en los titulares de prensa sobre los temas de comunicación: análisis de la construcción de discursos hegemónicos a partir de las auto-referencias hacia la comunicación. Razón y Palabra, n. 74, 2010.

English and Spanish

10) CHIHU, A. El "análisis del los marcos" en el discurso de Bush (septiembre 11 de 2001). Comunicación y Sociedad, n. 6, p. 159$181,2006$.

\section{References}

BROWN, G; YULE, G. Discourse analysis. Cambridge: Cambridge University Press, 1983.

CHRISTIE, F.; DEREWIANKA, B. School discourse: learning to write across the years of schooling. London: Continuum, 2008.

DEREWIANKA, B. Language development in the transition from childhood to adolescence: the role of grammatical metaphor. Unpublished PhD thesis. Department of English and Linguistics. Macquarie University, 1995.

HALLIDAY, M.A.K. An introduction to functional grammar. London: Arnold, 1985.

An introduction to functional grammar. $2^{\text {nd }}$. ed. London: Arnold, 1994.

HALLIDAY, M.A.K.; MATTHIESSEN, C.M.I.M. Construing experience through meaning: a language-based approach to cognition. London: Continuum, 1999. 
An introduction to functional grammar. $3^{\text {rd }}$. ed. London: Arnold, 2004.

Halliday's introduction to functional grammar. $4^{\text {th }}$ ed. London: Routledge, 2014.

HASAN, R. The conception of context in text. In: FRIES, P.H.; GREGORY, $M$. (eds.). Discourse in society: systemic functional perspectives:

Daniel meaning and choice in language: studies for Michael Halliday. New RodríguezJersey: Ablex, 1995. p. 183-269.

Vergara

HYLAND, K. Hedging in scientific research articles. Amsterdam: Benjamins, 1998.

Disciplinary differences: language variation in academic discourses. In: HYLAND, K.; BONDI, M. (eds.). Academic discourse across disciplines. Bern: Peter Lang, 2006. p. 17-45.

MATTHIESSEN, C.M.I.M. Lexicogrammatical cartography: English systems. Tokyo: International Language Sciences Publishers, 1995.

MATTHIESSEN, C.M.I.M.; TERUYA, K.; LAM, M. Key terms in systemic functional linguistics. London: Continuum, 2010.

MARTIN, J.R.; WHITE, P.R.R. The language of evaluation: appraisal in English. New York: Palgrave Macmillan, 2005.

SWALES, J.M. Genre analysis: English in academic and research settings. Cambridge: Cambridge University Press, 1990.

Research genres: explorations and applications. Cambridge: Cambridge University Press, 2004. 